\title{
Models Application of Fertilization on Onion and Okra Cropping Pattern as A Barier Plant
}

\author{
Made Sri Yuliartini ${ }^{*}$, Luh Kartini ${ }^{2}$ \\ ${ }^{1}$ Agrotechnology Program, Faculty of Agriculture, Universitas Warmadewa, Denpasar, Bali- \\ Indonesia \\ \{yuliartinisri@yahoo.co.id ${ }^{1}$ \}
}

\begin{abstract}
This research was to obtain a model of the correct combination of rabbit compost and NPK Mutiara in onion and okra cropping patterns. This experiment consisted of two factors: the dose of rabbit compost with 4 levels: $\mathrm{K} 0=0 ; \mathrm{K} 1=5 ; \mathrm{K} 2=$ $10 ; \mathrm{K} 3=15$ ton ha- 1 and dosage of NPK Mutiara with 3 levels : N1 = 100; N2 = 200; N3 $=300 \mathrm{~kg}$ ha- 1 . The interaction has no significant effect on all variables. The highest fresh weight of shallot tubers per clump and okra fruit per plant were found in $\mathrm{K} 3: 64.69 \mathrm{~g}$ and $194.24 \mathrm{~g}$, increasing $73.48 \%$ and $53.55 \%$ compared to $\mathrm{K} 0: 37.29 \mathrm{~g}$ and $126.50 \mathrm{~g}$. The highest fresh weight of shallot tubers per clump and okra fruit per plant were found at N3 : $58.77 \mathrm{~g}$ and $171.63 \mathrm{~g}$, an increase of $23.59 \%$ and $15.08 \%$ compared to N1: 47.55 $\mathrm{g}$ and $149.14 \mathrm{~g}$.
\end{abstract}

Keywords: Fertilization Model; Cropping Pattern; Onion; Okra Plants.

\section{Introduction}

Increasing the intensity of okra cultivation, especially in Bali, requires appropriate technology, namely by utilizing local resources and not focusing on one plant so as to provide increased yields and income. Okra plants can be combined with onion plants in a single cropping system. The intercropping cropping pattern creates a complex cropping agroecosystem, which includes interactions between similar and different types of plants. Okra plant is a vegetable plant that contains high fiber and contains mucus, which is consumed as young fruit, cooked as vegetables or as fresh vegetables [1]. Onion is a spice vegetable which, although not native to Indonesia, is used as a delicious spice in Indonesian dishes. Almost all Indonesian dishes use onions as a flavoring [2]. The selection of plants in intercropping is based on differences in morphology and physiology, plants compete for light and nutrients. To increase yields in plants with an intercropping cropping system, it is necessary to have sufficient nutrient availability so that the plants can grow and give good results. So competition between plants for nutrient uptake is not at a detrimental level. This needs to return to the organic system by utilizing rabbit waste as fertilizer, so as to improve the environment in which plants grow. The provision of organic fertilizers needs to be balanced with inorganic fertilizers. How big the dosage of organic fertilizers is combined with inorganic fertilizers has an effect on yields in plants with intercropping systems. The intercropping system of okra with onions was able to provide a higher fresh weight of okra fruit per plant, namely $892.33 \mathrm{~g}$ which increased by $9.44 \%$ and $10.33 \%$ when compared to the intercropping 
system between okra and kale which was $815.33 \mathrm{~g}$ and the intercropping system okra and mustard greens, namely $808.75 \mathrm{~g}$ [3].

\section{Research Methods}

The research was conducted in rice fields in Sanding Village, Tampak Siring District, Gianyar Regency, starting from April to October 2020. The research method used a factorial randomized block design, consisting of two factors, namely the dosage of rabbit compost and NPK pearl fertilizer (16:16:16). ). The dosage of Rabbit Compost (K) consists of 4 levels, namely: $\mathrm{K} 0=0$ tonnes ha- $1 ; \mathrm{K} 1=5$ tonnes ha-1; $\mathrm{K} 2=10$ tonnes ha- $1: \mathrm{K} 3=15$ tonnes ha- 1 and the dosage of NPK Mutiara (N) consists of 3 levels, namely: N1 $=100 \mathrm{~kg}$ ha-1: N2 $=200$ $\mathrm{kg}$ ha-1; N3 $=300 \mathrm{~kg}$ ha- 1 . So that the 12 combination treatments were repeated 3 times, so that 36 experimental plots were needed. The research implementation included land preparation, making 36 plots of $2 \times 2 \mathrm{~m}$ size with $20 \mathrm{~cm}$ mound height, $30 \mathrm{~cm}$ spacing between plots and $50 \mathrm{~cm}$ between replicates; planting is done in the afternoon, for shallot seeds before planting, cut the ends of $1 / 3$ part then planted with a depth of $3 \mathrm{~cm}$ with a spacing of $20 \times 20 \mathrm{~cm}$ on a plot area of $1.5 \times 1.5 \mathrm{~m}$; for okra seeds planted as barrier plants in plots with a spacing of $50 \mathrm{~cm}$. Giving treatment of rabbit compost was given 1 week before planting according to the treatment while NPK Mutiara fertilizer was given 2 times, namely 2 weeks and 4 weeks after planting according to the treatment. Maintenance includes watering, replanting, weeding and controlling pests and diseases. Harvesting is done after the onion and okra plants are 60 days old., according to the harvest criteria. The variables observed in onion and okra plants included plant height, number of leaves, number of onion tubers, number of okra fruits, fresh weight of tubers and fresh weight of okra and stover weight of onions. The data were analyzed statistically using diversity analysis.

\section{Results and Discussion}

The results of statistical analysis of all observed variables showed the significance of the dose of rabbit compost $(\mathrm{K})$ and NPK Mutiara $(\mathrm{N})$ fertilizer and its interaction $(\mathrm{KxN})$ ) on the observed variables which are presented in Table 1 .

Tabel 1. The significance of rabbit compost (K) and NPK Mutiara $(\mathrm{N})$ fertilizer doses and their interactions $(\mathrm{KxN})$ on all observed variables

\begin{tabular}{|c|c|c|c|c|}
\hline \multirow[b]{2}{*}{ No } & \multirow[b]{2}{*}{ Variables } & \multicolumn{2}{|c|}{ Treatment } & \multirow[b]{2}{*}{$(\mathrm{KxN}$} \\
\hline & & (K) & (N) & \\
\hline 1 & Maximum plant height of shallots $(\mathrm{cm})$ & ns & ns & ns \\
\hline 2 & Maximum number of red hot leaves (strands) & $* *$ & ns & ns \\
\hline 3 & Number of tubers per hill (tubers) & ns & ns & Ns \\
\hline 4 & Fresh weight of shallot tubers per clump (g) & $* *$ & $* *$ & Ns \\
\hline 5 & Fresh weight of stover per clump (g) & $* *$ & ns & Ns \\
\hline 6 & Maximum okra plant height $(\mathrm{cm})$ & ns & ns & ns \\
\hline 7 & Number of okra plant leaves (strands) & $* *$ & ns & ns \\
\hline 8 & Number of okra fruits per plant (fruit) & $* *$ & $\mathrm{~ns}$ & ns \\
\hline
\end{tabular}


$\frac{9 \quad \text { Fresh weight of okra fruit per plant }(\mathrm{g}) \quad * * \quad * * \quad \mathrm{~ns}}{\text { Note: } \mathrm{ns}=\text { not significant }(\mathrm{P} \geq 0.05), *=\text { significant }(\mathrm{P}<0.05), * *=\text { very significant }}(\mathrm{P}<0.01)$.

From Table 1 it can be seen that the interaction of rabbit compost dose with NPK Mutiara fertilizer $(\mathrm{KxN})$ has no significant effect $(\mathrm{P} \geq 0.05)$ on all observed variables. The dose of rabbit compost $(\mathrm{K})$ had a very significant effect $(\mathrm{P}<0.01)$ on the number of spring onions, fresh weight of tubers per clump, fresh weight of stover per clump, number of leaves of okra plants, number of okra fruit per plant and fresh weight of okra fruit. per plant and had no significant effect $(\mathrm{P} \geq 0.05)$ on shallot plant height, number of tubers per hill and height of okra plants. The dosage of NPK Mutiaral fertilizer $(\mathrm{N})$ had a very significant effect $(\mathrm{P}<0.01)$ on tuber fresh weight per clump and fresh weight of okra fruit per plant and had no significant effect $(\mathrm{P} \geq 0.05)$ on other variables. The average values of the observed variables at the dose of rabbit compost $(\mathrm{K})$ and NPK Mutiara $(\mathrm{N})$ fertilizers and their interactions are presented in Table 2 and Table 3.

Tabel 2. The average value of the observed shallot plant variables at the dose of rabbit compost $(\mathrm{K})$ and NPK Mutiata fertilizer (N)

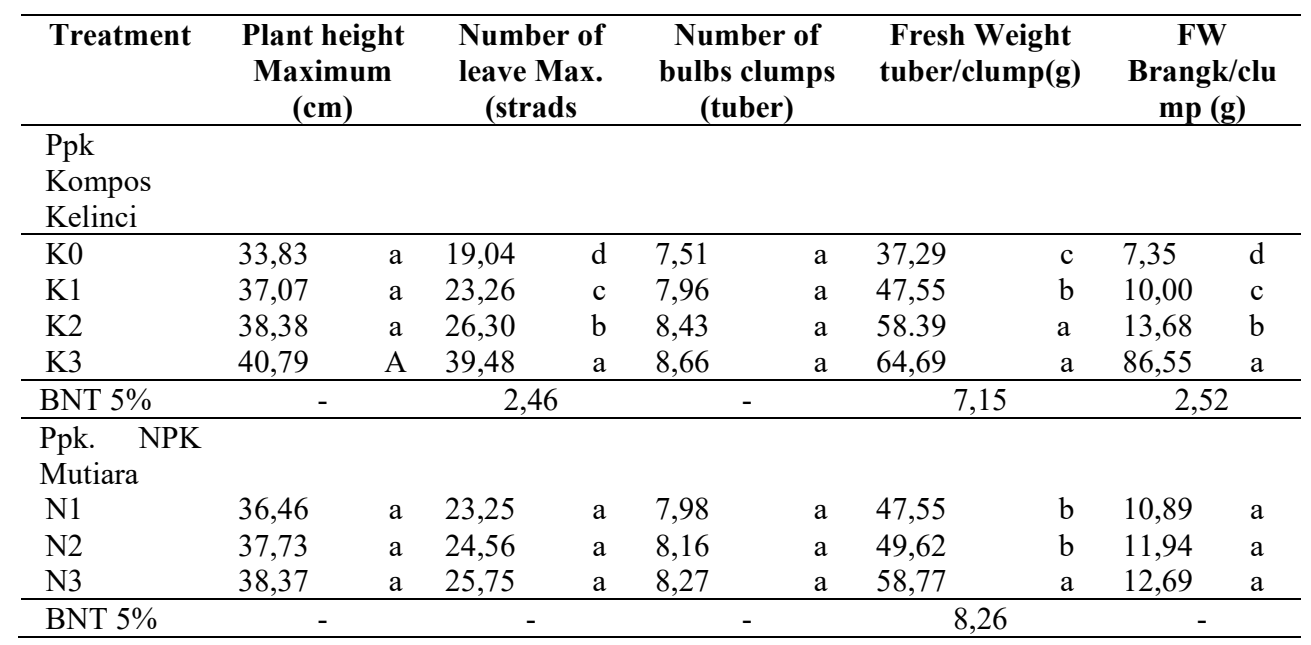


Tabel 3. The average value of the observed okra plant variables at the dose of rabbit compost (K) and NPK Mutiata fertilizer $(\mathrm{N})$

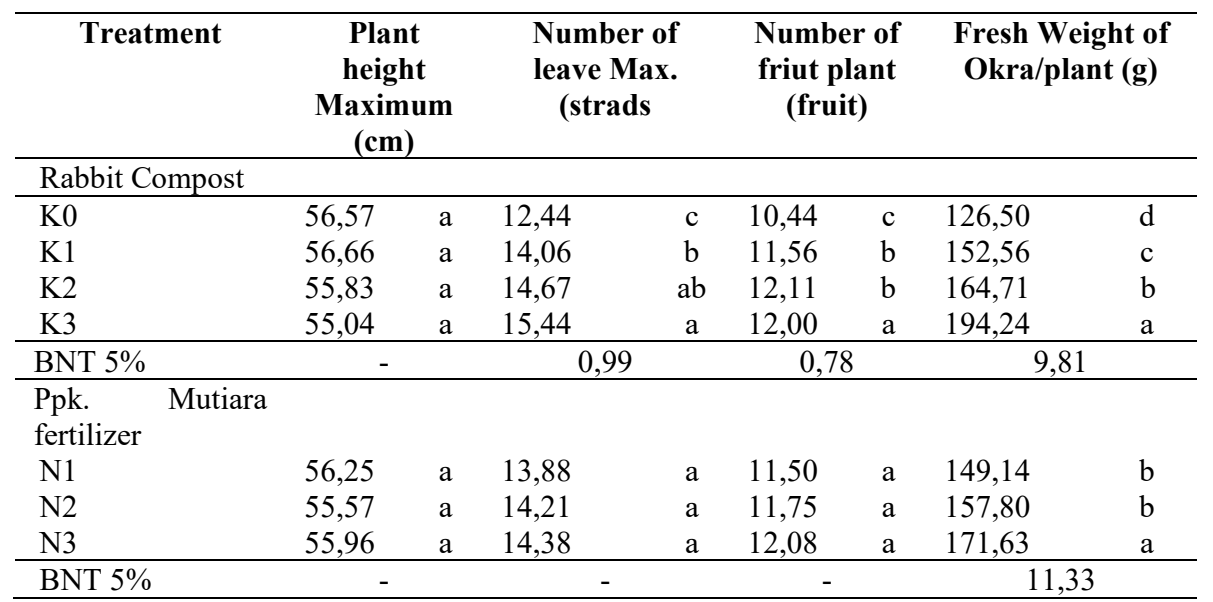

Note: The average value followed by the same letter in the same treatment and column is not significantly different at the 5\% LSD test level.

The dose of rabbit compost $(\mathrm{K})$ had a very significant effect on fresh weight of shallot tubers per hill and fresh weight of okra fruit per plant. The provision of rabbit compost increased the fresh weight of shallot tubers per hill and the fresh weight of okra fruit per plant was getting higher. The highest fresh weight of shallot tubers was obtained when the dose of rabbit compost was 15 tons. ha-1 was not significantly different from the dose of rabbit compost 10 tons. ha-1, namely $64.69 \mathrm{~g}$ and $58.39 \mathrm{~g}$, an increase of $73.48 \%$ and $56.58 \%$ compared with the lowest fresh weight of tubers per clump, namely $37.29 \mathrm{~g}$ at a dose of 0 ton.ha-1 rabbit compost (Table 2 and Table 3 ). This is due to the provision of rabbit compost to improve the physical, chemical and biological properties of the soil and increase the availability of nutrients in the soil. Rabbit compost has the advantage that it can increase plant resistance to attack by a number of plant-disturbing organisms and can increase the activity of microorganisms in the soil which can help increase soil fertility, increase nutrient content in the soil, help maintain soil moisture, contain macro and micro nutrients that have a very good influence on the improvement of the physical properties of the soil and especially the biological properties of the soil, and it is safe to use in large quantities and does not damage the environment [4]. This can be seen by giving rabbit compost of 15 tons. ha- 1 can increase the number of leaves on onion and okra plants, namely 29.48 and 15.44 pieces; The number of shallot tubers is 8.66 tubers and the number of okra plants is 13 (Table 2 and Table 3). The increasing number of leaves will lead to increased photosynthesis so that the photosynthate produced is more translocated to increase the fresh weight of tubers per clump and the weight of fruit per plant. [5] Stated that the increased interception of sunlight by leaves to produce photosynthate and in subsequent development this photosynthate will be transferred to plant organs that actively carry out metabolic processes so that growth becomes better and will subsequently affect plant yields.

The dose of NPK Mutiara fertilizer $(\mathrm{N})$ had a very significant effect on tuber fresh weight per clump and fresh weight of okra fruit per plant. The highest fresh weight of shallot tubers per clump and fresh weight of okra fruit per plant were obtained at the NPK Mutiara 300 kg.ha-1 fertilizer dosage, namely $58.77 \mathrm{~g}$ and $171.63 \mathrm{~g}$, an increase of $23.59 \%$ and $15.08 \%$ 
respectively. The lowest fresh weight was $47.55 \mathrm{~g}$ and $149.14 \mathrm{~g}$ at the NPK Mutiara fertilizer dose of $100 \mathrm{~kg}$.ha-1 (Tables 2 and 3). This is due to the function of each nutrient contained in NPK Mutiara fertilizer for vegetative and generative growth of shallot and okra plants. Plant growth and yield are determined by the rate of photosynthesis which is controlled by the availability of nutrients. Nitrogen plays a role in increasing plant growth, especially the vegetative part, namely the stems, branches, plant height, leaf and leaf area [6]. [7] States that the size, diameter and quality of flowers in the generative phase will be greatly influenced by the availability of $\mathrm{K}$ nutrients, while the $\mathrm{P}$ nutrient plays a role in the formation of flowers which later become fruit. [8] States that NPK affects the weight of flowers, which plays a role in the formation chlorophyll is $\mathrm{N}$ so that the process of photosynthesis is processed optimally resulting in increased growth and yield, $\mathrm{K}$ has the role of forming protein and carbohydrates, strengthening flowers and leaves so they do not fall easily. The results of research [9] that phosphorus is one of the essential nutrients needed by plants for optimum growth and yield. The nutrients that have been absorbed by the roots, especially the nutrients Phosphorus (P), contribute to the weight gain of tubers per hill.

\section{Conclusions}

From the research it can be concluded: The interaction of rabbit compost dose with NPK Mutiara fertilizer has no significant effect on all observed variables. The doses of rabbit compost and NPK Mutiara fertilizer had a very significant effect on fresh weight of shallot tubers per clump and fresh weight of okra fruit per plant. The highest fresh weight of shallot tubers per clump and fresh weight of okra fruit per plant were obtained at the dose of 15 ton.ha- 1 rabbit compost, namely $64.69 \mathrm{~g}$ and $194.24 \mathrm{~g}$ which increased by $73.48 \%$ and 53 , $55 \%$ compared to the dose of 0 ton.ha- 1 rabbit compost, namely $37.29 \mathrm{~g}$ and $126.50 \mathrm{~g}$. The highest fresh weight of shallot tubers per clump and fresh weight of okra fruit per plant were obtained at the NPK Mutiara fertilizer dosage of $300 \mathrm{~kg}$.ha-1, namely $58.77 \mathrm{~g}$ and $171.63 \mathrm{~g}$, an increase of $23.59 \%$ and $15.08 \%$ compared to the NPK Mutiara fertilizer dosage of $100 \mathrm{~kg}$.ha1 , namely $47.55 \mathrm{~g}$ and $149.14 \mathrm{~g}$.

The suggestions put forward in this study are; It is necessary to do further research at different places and times with different dosage combinations in order to obtain a real interaction.

\section{Acknowledgment}

The author would like to thank the Dean, Chair of the Agrotechnology Study Program, and the Head of the Experimental Station of the Faculty of Agriculture, Warmadewa University, for facilitating this research. Thank you also to fellow students who have helped and supported this research.

\section{References}

[1] S. Benchasri, "Okra (Abelmoschus esculentus L.) Moench) as a Valuable Vegetable 
of the World," Ratar.Povrt, vol. 49, no. 10. pp105-112, 2012.

[2] Setiyowati, S. Haryanti, and R. Hastuti, "Pengaruh Perbedaan Konsentrasi Pupuk Organik Cair tehadap Produksi Bawang Merah (Allium ascalonicum L), "Bioma : Berkala Ilmiah Biologi, vol. 12, no. 2, pp. 44-48, Apr. 2012. https://doi.org/10.14710/bioma.12.2.44-48

[3] M. S. Yuliartini, dan L. Kartini, "Pengaturan Ruang Tumbuh Dalam Sistem Tumpang Sari Tanaman Okra Dan Sayuran," Fak Pertanian Universitas Warmadewa, 2019.

[4] Y. C. Sajimin, Rahardjo, D. Nurhayati, and Purwanti. "Potensi Kotoran Kelinci Sebagai Pupuk Organik dan Manfaatnya Pada Tanaman Sayuran. Lokarya Nasional Potensi dan peluang Pengembangan Usaha Agribisnis Kelinci," Balai Penelitian Ternak Bogor, 2005.

[5] T. S. P. Mulat, "Membuat Dan Memanfaatkan Pupuk Organik Berkualitas," Jakarta: Agromedia Pustaka, 2003.

[6] N. Lindawati, Izhar dan H. Syafria, "Pengaruh Pemupukan Nitrogen Dan Interval Pemotongan Terhadap Produktivitas Dan Kualitas Rumput Lokal Kumpai Pada Tanah Podzolik Merah Kuning," J. Pengkajian dan Pengembangan Teknologi Pertanian, vol. 2, no. 2, pp.130-133, 2000.

[7] S. Birnadi, "Respons Mentimun Jepang (Cucumis sativus L.) Var. Roberto terhadap Perendaman Benih dengan Giberelin (GA3) dan Bahan Organik Hasil Fermentasi (Bohasi)," J. Istek, vol. 10, no. 2, 2017.

[8] V. S. Suwarno, N. Pomalinggo, and Nurmi, "Respon Pertumbuhan dan Produksi Tanaman Mentimun (Cucumis sativus L.) Melalui Perlakuan Pupuk NPK Pelangi," UNG Repository, 2013.

[9] Z. He, S. T. Griffin, and C. W. Honey, "Evaluation Of Soil Phosphorus Transformation By Sequential, Fractionation And Phosphorus Hydrolysis," J. Soil Science, vol. 169, no. 7, pp 515-527, 2004 